\title{
The Riming Proportion in Snow Particles Falling on Coastal Areas
}

\author{
By Toshio Harimaya and Misao Sato ${ }^{1}$ \\ Department of Geophysics, Faculty of Science, Hokkaido University, Sapporo 060, Japan \\ (Manuscript received 25 February 1991, in revised form 18 November 1991)
}

\begin{abstract}
When studying snow-particle formation and precipitation mechanisms, it is important to examine the ratio of the contribution of each process - such as deposition, riming, and aggregation - to the growth of a snow particle. In the winter monsoon season, measurements were made of the contribution ratio of the riming process to snow-particle growth by the method of Harimaya and Sato (1989). Snowfall in which the riming process was predominant in the growth of snow particles (i.e. snowfall having a rime mass of more than $50 \%$ of the total mass) accounted for about $70 \%$ of total snowfall frequency along the coastal areas toward the Japan Sea. Over the coastal areas, the deposition process did not contribute to strong snowfall intensity, being controlled instead by the riming process.

It has generally been considered that snow clouds in the developing and mature stages pass over coastal areas more frequently than over inland areas, as snow clouds move from the sea toward the land. It has been observed that the riming process was predominant during the developing and mature stages of snow clouds. It follows from these that the riming process is predominant in snowfall along coastal areas where such snow clouds often pass.
\end{abstract}

\section{Introduction}

It is well known that snow particles grow through the processes of deposition, riming, and aggregation. When investigating snow-particle formation and precipitation mechanisms it is important to examine the ratio of the contribution of each process to the growth of a snow particle. This will build the foundation for the possibility of artificial modification of snow clouds in the future. However, such quantitative investigations have not been made as yet.

Lines of cumulus clouds, referred to as cloud streets or band clouds move from the sea toward the land, parallel to the wind direction. They cause the horizontal distribution of snowfall to be bandshaped (e.g. see Higuchi, 1963). Graupel or densely rimed snow crystals then fall near the coastal areas while lightly rimed or non-rimed snow crystals fall over inland areas (Magono et al., 1964, 1966). These are the characteristic features of Japan's snowfall phenomena during the winter monsoon season in the coastal areas toward the Japan Sea.

There have been many quantitative studies on the riming properties of snow crystals, such as the size of onset of riming on snow crystals, the relationship between the crystal's shape and riming properties, and the cutoff diameter of droplets accreted on snow

\footnotetext{
${ }^{1}$ Present Affiliation: Hokkaido Branch, Japan Weather Association, Sapporo.

(c) 1992, Meteorological Society of Japan
}

crystals (e.g. Harimaya, 1975). However, only a few qualitative studies have been conducted regarding the amount of rime on snow crystals. For example, Hobbs et al. (1971) classified the degree of rime on particles into five categories such as unrimed, lightly rimed, moderately rimed, densely rimed particles, and graupel. They compared the degree of riming in snowfall among several observational sites in the Cascade Mountains of the United States. At the crest of the Cascades, the rate of precipitation was found to increase as the riming increased, but at stations on the eastern slopes this correlation was not seen. Reinking $(1975,1979)$ classified rime into six categories, pointing out that the degree of rime increased with the size of the snow crystals for snowfall on the western slope of the Sierra Nevada, also in the United States. Fujiyoshi and Wakahama (1985) unfastened snowflake aggregates with a bamboo skewer, classifying the snow particles which made up the aggregates into three types according to the degree of rime. They calculated the ratios of the number of snow particles for each type to the total number, representing the degree of riming of aggregates by the ratios. The relationship between the degree of riming and snowfall intensity was then studied; it was found that snowfall intensity did not necessarily increase with an increase in the degree of riming of snow crystals.

Harimaya and Sato (1989) developed quantitative measuring methods to determine the amount of rime 


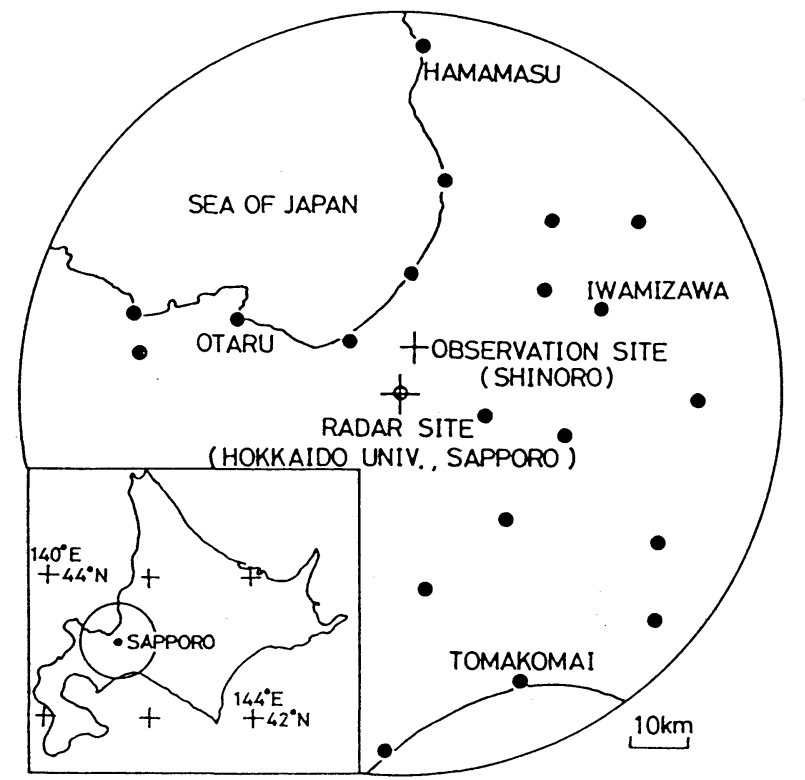

Fig. 1. Location of the observation site. The solid circles represent the Automated Meteorological Data Acquisition System of the Japan Meteorological Agency (AMeDAS) points.

on snowflakes. Mitchell et al. (1990), then developed a similar method to that of Harimaya and Sato (1989). With the ability to quantitatively measure the amount of rime on snowflakes, observations have been carried out to determine the riming proportion to snowfall amount at a site in the coastal areas toward the Japan Sea. Here, the riming growth process is considered to contribute to a large extent to the growth of snow particles. In the present paper, on the basis of observational data, we shall examine the contribution ratio of the riming growth process to snowfall amount on the coastal areas. Also, we shall clarify the difference in the riming proportion in the growth of snow particles due to different meteorological conditions and different growth stages of snow clouds.

\section{Observations}

Observations were carried out in the area of the Ishikari Plain, in Hokkaido, Japan, from January to February 1987. The behavior of the snow clouds over the area was observed by the radar at the Faculty of Science, Hokkaido University. The surface observation site was at Shinoro, located about 7.9 $\mathrm{km}$ toward the north-northeast of the radar site (see Fig. 1), and about $10 \mathrm{~km}$ from the sea-coast along the direction of the prevailing wind of the winter monsoon. The observation variables were as follows; Snowfall intensity measured over one minute, riming proportions by the disassembly method and filter-paper absorption method every ten minutes, the size distribution of snow particles, microscope

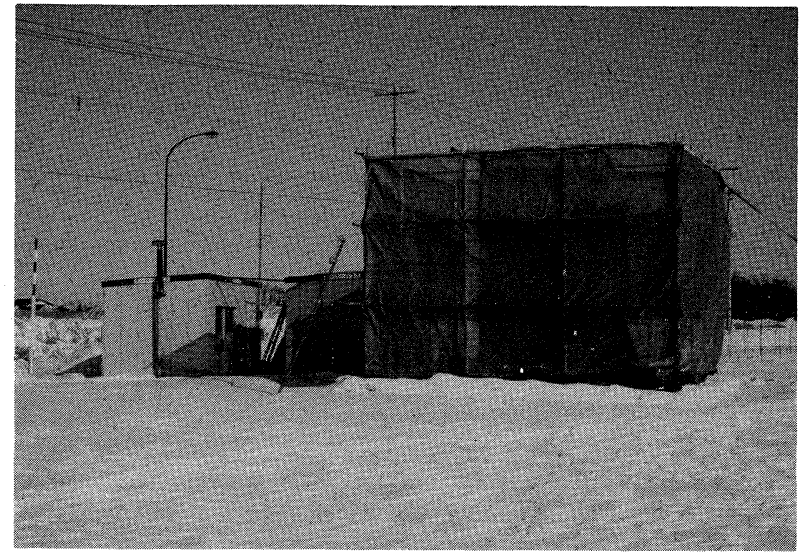

Fig. 2. The double wind breaker net structure and two observational huts at the site for snow particle observations. The wind breaker net structure consists of double nets $5 \mathrm{~m}$ by $5 \mathrm{~m}$ by $4 \mathrm{~m}$ in height and 2 $\mathrm{m}$ by $2 \mathrm{~m}$ by $4 \mathrm{~m}$ in height.

observations of the snow crystals, and general meteorological conditions.

Regarding the measurement of snowfall intensity and the collection of snow particles, the influence of the strong wind during the winter monsoon season must be excluded. For this purpose a wind breaker net $5 \mathrm{~m}$ by $5 \mathrm{~m}$ by $4 \mathrm{~m}$ in height was installed as shown in Fig. 2. Also, a net formation $2 \mathrm{~m}$ by $2 \mathrm{~m}$ by $4 \mathrm{~m}$ in height was constructed inside to enhance the effect of the wind breaker. Since the snow particles fell vertically in the double wind breaker net structure even if the wind reached $10 \mathrm{~m} / \mathrm{sec}$ in the surrounding area, an accurate measure of snowfall intensity could be obtained at a one minute interval.

The values of riming proportion by the disassembly method were used in the following analyses and discussions. The measurement was made as follows. Snowflakes were captured on a wood board covered with velvet cloth. One snowflake having the mean degree of rime amount in the snowflakes was selected as a representative sample. On a glass plate, the snowflake was disassembled into individual snow crystals by a bamboo skewer in such a way that these did not fracture. All the snow crystals that constituted the one snowflake were then photographed. The work was accomplished in a cold observational hut. Based on the photographs, the snow crystals which constituted one snowflake were classified by the degree of rime. The size and number of the snow crystals for each type were then obtained. Next, the mass and the mass of rime for each snow crystal were obtained from the size, using an empirical formula for each snow crystal type. The total mass and total mass of rime were then summed for all of the snow crystals which constituted one snowflake. The 
riming proportion was found by the ratio of the total mass of rime to the total mass constituting one snowflake, according to the method of Harimaya and Sato (1989). The measurements were carried out at a 10 minute interval.

Snowfall intensity was measured by equipment which was of type similar to that developed by Konishi et al. (1988). It consisted of an electro-balance with the minimum detectable weight of $0.1 \mathrm{~g}$, a bucket of $34.4 \mathrm{~cm}$ in diameter, and a portable computer connected to the electro-balance. The electrobalance automatically measured the weight of snowfall in the bucket calculating the snowfall intensity at a one minute interval. The minimum detectable snowfall intensity of this equipment was found to be $0.065 \mathrm{~mm} / \mathrm{hr}$ when the weight increased by 0.1 $\mathrm{g} / \mathrm{min}$. The portable computer was set in a warm observational hut.

The radar coverage area was that swept by a radius of $63.5 \mathrm{~km}$. Three dimensional digital data of the equivalent radar reflectivity factor were obtained by changing the elevation angle of the antenna from 0 to 20 degree every ten minutes. The data consisted of values on $1 \mathrm{~km} \times 1 \mathrm{~km}$ grid in the horizontal plane and $0.15 \mathrm{~km}$ interval in the vertical plane. Moving Target Indicator (MTI) signal processing was used for removing ground clutter, applying a range correction for the attenuation.

\section{Results}

\subsection{The relationship between meteorological condi- tions and riming proportion}

In order to study the difference in riming proportion due to meteorological conditions, the meteorological conditions were examined for the days when the riming proportion was measured. Winter monsoon winds prevailed on all days when the riming proportion was measured. There were also many different radar echo patterns. The radar echo patterns were then classified into three types, such as diffused echoes, convective echoes, and band-shaped convective echoes as shown in Fig. 3. This classification was used as an indication of the meteorological conditions. Since snow clouds lined up in a northwest to southeast direction and move in the direction of the northwest monsoon wind, the map is drawn such that the northwest to southeast direction becomes horizontal in the panels.

The upper panel of Fig. 3 shows the horizontal distribution of radar echoes at 0210 JST 5 February, as a representative example of the diffused echoes which appeared between 2350 JST 4 and 0910 JST 5 February. During this period, radar echoes had characteristic features as follows. They were formed over the sea near the coast and moved in a southeast direction. They then dissipated over land, in an area located about $20 \sim 25 \mathrm{~km}$ from the coast. As a whole, the radar echoes had a stratiform structure and their
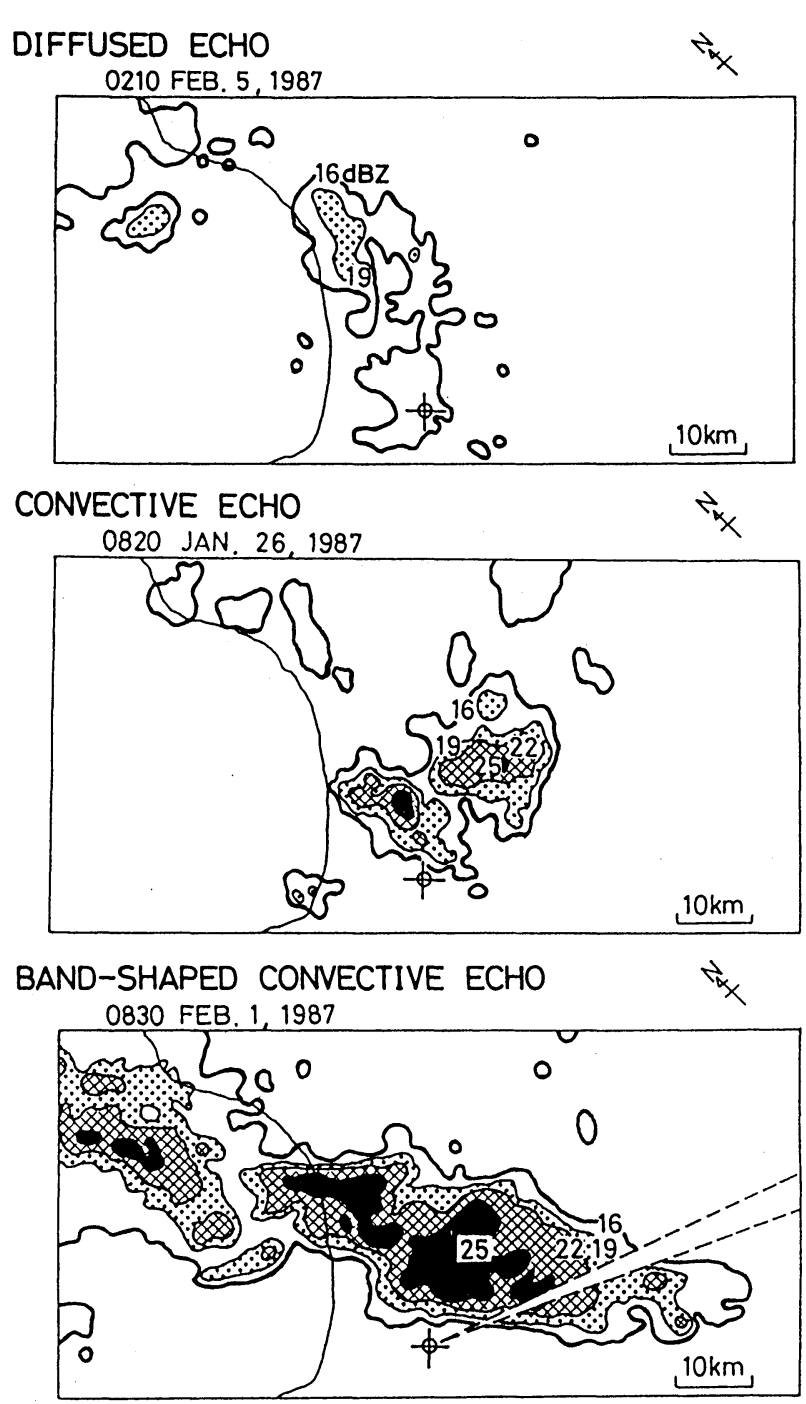

Fig. 3. The classification of radar echo patterns. The radar echo patterns show examples of diffused echoes (top), convective echoes (middle) and band-shaped convective echoes (bottom). Arrows indicate the northward direction.

intensities were not very strong. The middle panel shows that at 0820 JST during the period of convective echoes at 0810 JST to 1100 JST, 26 January. These radar echoes were formed over the sea near the coast and moved in an eastward direction. As soon as they reached landfall on the Ishikari Plain, they suddenly developed. They then dissipated over an area about $40 \mathrm{~km}$ from the coast. They were characterized by convective structure about $10 \mathrm{~km}$ to $20 \mathrm{~km}$ in size. The lower panel shows radar echoes at 0830 JST during the period of band-shaped convective echoes between 0200 JST and 1200 JST, 1 February. Over this period, the radar echoes were band shaped and extended from the sea to an area about $50 \mathrm{~km}$ from the coast and were aligned in a northwest to southeast direction. The band- 
Table 1. List of the radar echo patterns and the time of their occurrence.

\begin{tabular}{ll}
\hline DIFFUSED. ECHO & 2350 FEB. 4-0910 FEB. 5, 1987 \\
\hline CONVECTIVE ECHO & $0810-1100$ JAN. 26,1987 \\
& $1450-1640$ FEB. 5,1987 \\
\hline BAND-SHAPED CONVECTIVE ECHO & $0200-1200$ FEB. 1,1987 \\
& $1650-2300$ FEB. 5,1987 \\
\hline
\end{tabular}

shaped convective echoes consisted of strong echo areas $10 \sim 20 \mathrm{~km}$ in size. Although each component cell of the band-shaped convective echoes moved in the direction of the band shape, the overall pattern of the band-shaped convective echo continued to exist at almost the same location. Component cells developed strongly in an area about $20 \mathrm{~km}$ inland from the coast.

Convective echoes were observed from 1450 JST to 1640 JST, 5 February, and band-shaped convective echoes from 1650 JST to 2300 JST, 5 February, except for the data shown above. Periods and radar echo patterns analyzed in this paper are listed in Table 1.

The change in the snowfall intensity and riming proportion for each echo pattern when the snow clouds passed over the Shinoro site were then analyzed. Figure 4 shows the time change of the equivalent radar reflectivity factor over the Shinoro site, the snowfall intensity, frequency of snow crystals in each type and riming proportion at the Shinoro site for diffused echoes. In this analysis, each snow crystal was classified into one of three types, namely Type I, Type II, and Type III according to the degree of rime, while graupel particles were referred to as Type IV. It happens frequently that snowflakes and graupel particles fall simultaneously. In that case, it is necessary to take account of graupel particles in the estimation of the riming proportion (Harimaya and Sato, 1989). The procedures are as follows. The numbers are counted for snowflakes and graupel particles captured on a wood board covered with velvet cloth. If the riming proportion of graupel particles is assumed to be $100 \%$, the riming proportion $\left(R^{\prime} \%\right)$ incorporating the effect of graupel particles is given by

$$
R^{\prime}=\frac{R N_{s}+100 N_{g}}{N_{s}+N_{g}} \% .
$$

Here, $R$ is the riming proportion for only snowflakes in $\%, N_{s}$ and $N_{g}$ are the numbers of snowflakes and graupel particles captured on a wood board covered with velvet cloth, respectively. In the lower panel, the open circles indicate the riming proportion for only snowflakes while solid circles indicate the riming proportion incorporating the effect of graupel particles. With diffused echoes, at times only a few weak echo cells passed over the Shinoro site.
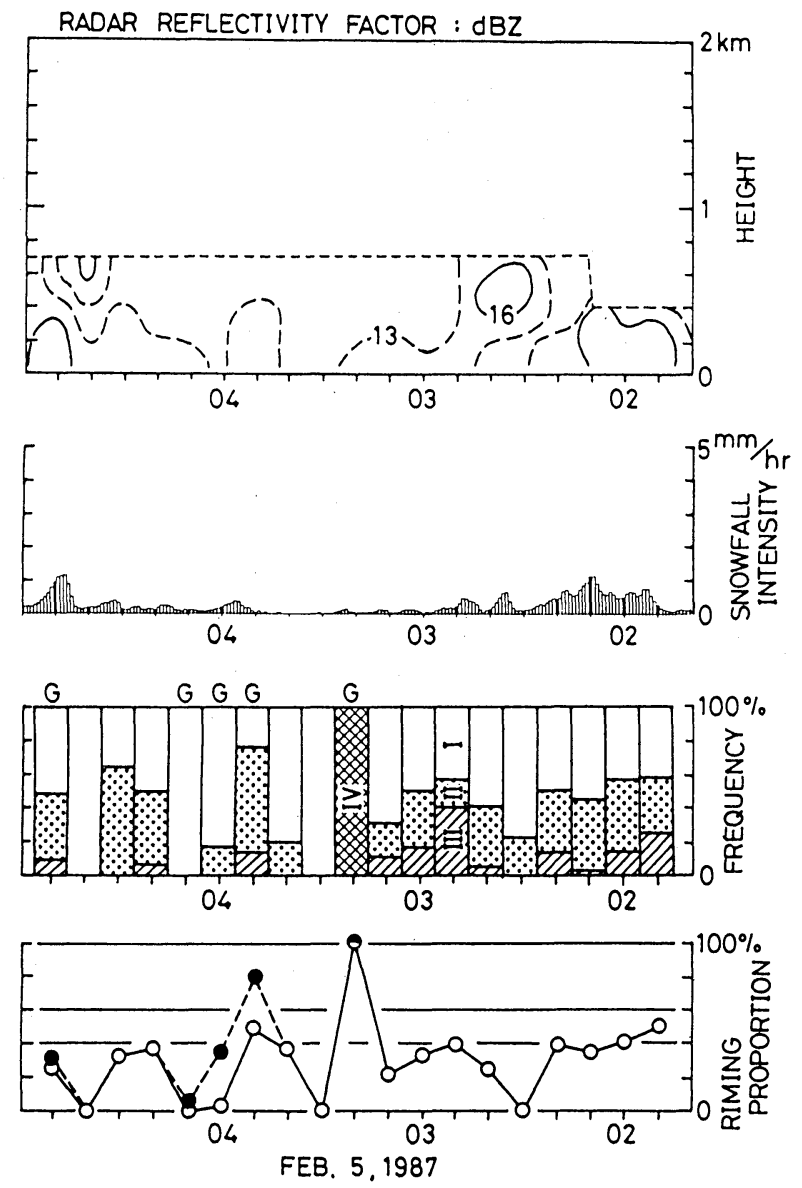

Fig. 4. Temporal changes in the equivalent radar reflectivity factor over the Shinoro site, snowfall intensity, frequency of snow crystals in each type (see the text) and riming proportion at the Shinoro site for diffused echoes. The letter $\mathrm{G}$ shows graupel particles which fell simultaneously with the snowflakes. In the lower panel, the open circles indicate the riming proportion for only snowflakes while the solid circles are the riming proportion incorporating the effect of graupel particles.

However, the snowfall intensity increased to about 1 $\mathrm{mm} / \mathrm{hr}$ with the passing of the weak echoes. Many of the snow crystals which constituted snowflakes were unrimed or lightly rimed particles, namely Type I. The riming proportion was less than $40 \%$. Therefore, it was concluded that the riming process 

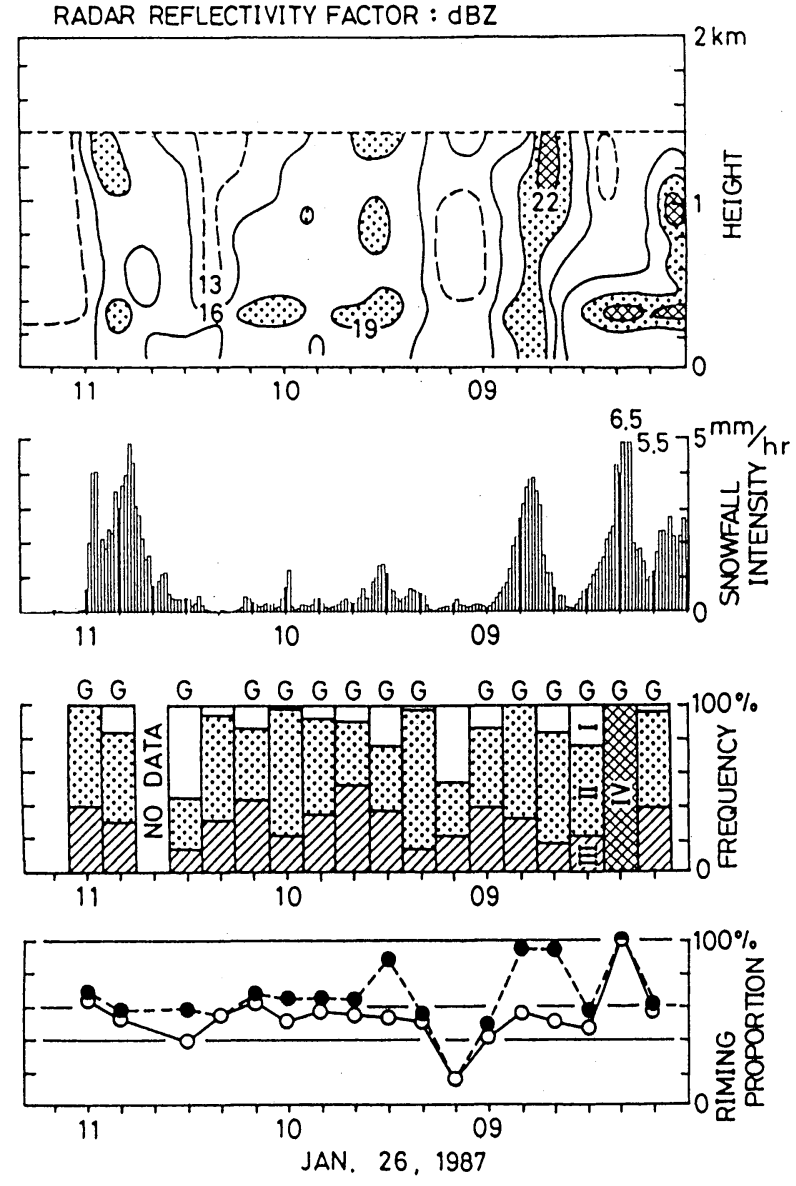

Fig. 5. As in Fig. 4 except for convective echoes.

was not predominant in the growth of snow particles for this case.

Figure 5 shows how the snowfall phenomena changed at the Shinoro site for convective echoes. Moderate convective echo cells often passed over the Shinoro site as shown during 0800 0900 JST and the snowfall intensity became stronger with the passing of the echo cells. When the snowfall intensity became stronger, snow particles with many cloud droplets fell, increasing riming proportion. The riming proportion was about $60 \%$ except for the period during a very strong snowfall. Therefore, it was concluded that the riming process dominated the growth of snow particles for this case.

Figure 6 exhibits the time change of the snowfall phenomena at the Shinoro site for band-shaped convective echoes. As a strong echo cell moved over the Shinoro site at about 0930 JST, the snowfall intensity increased, graupel particles fell, and riming proportion also increased. The snowfall intensity then continued to gradually increase and in contrast, the riming proportion gradually decreased. In the latter stage of the echo passage, both the snowfall intensity and riming proportion became small. This was the first time that these characteristic time
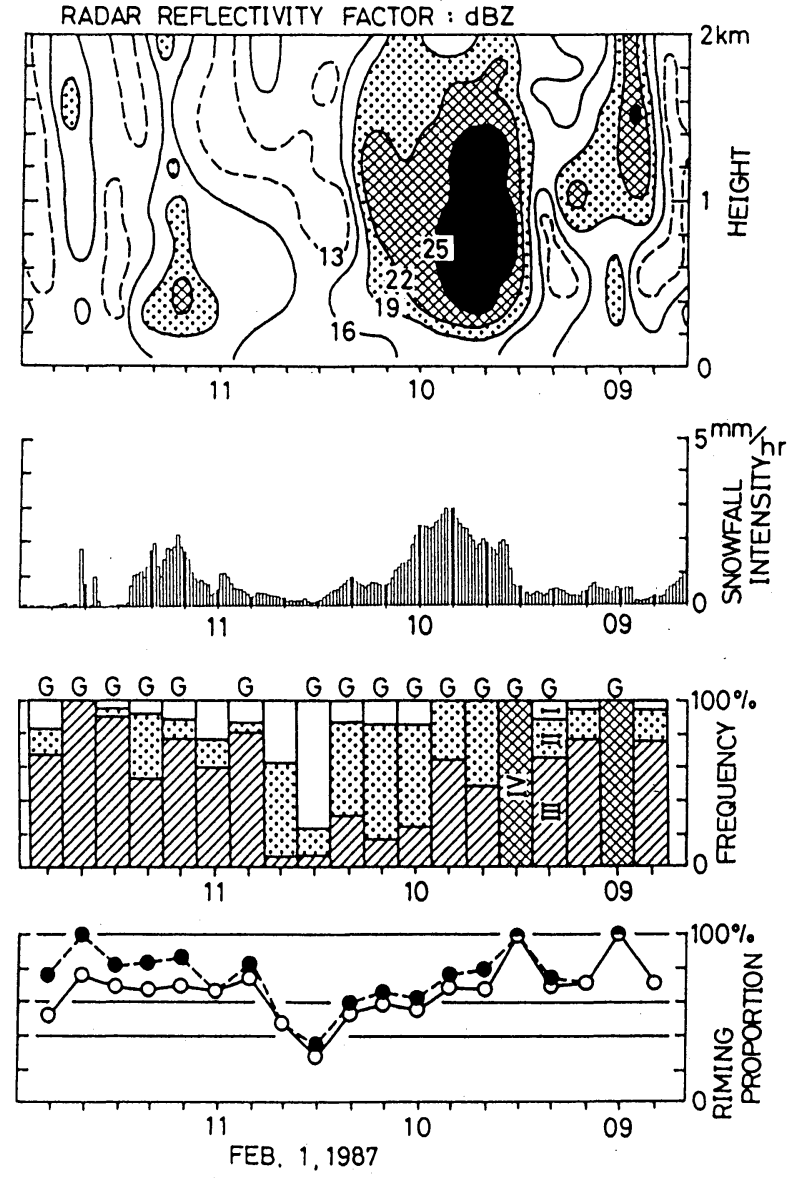

Fig. 6. As in Fig. 4 except for band-shaped convective echoes.

changes of snowfall intensity and riming proportion were quantitatively measured during the passage of strong echo cells. The riming proportion was near 80 $\%$ for band-shaped convective echoes, being higher than those under other conditions. Thus, it was concluded that the riming process was predominant in the growth of snow particles for this case.

It has been generally thought that the amount of rime accreted on snowflakes increases as the mixing ratio of graupel particles increases during a snowfall. This was first examined as follows. Figure 7 shows the relationship between the mixing ratio of graupel, which is defined as the number ratio of graupel particles to the total snow particles, and the riming proportion for only snowflakes. Although the riming proportion for snowflakes has values even when the mixing ratio of graupel is zero, the range narrows as the mixing ratio of graupel increases. This may indicate that there is a tendency for the riming proportion to increase as the graupel mixing ratio increases.

As was inferred in Figs. 4, 5, and 6, the riming proportion is related to the snowfall intensity. The relationship between the snowfall intensity and riming proportion is examined, as shown in Fig. 8. In 


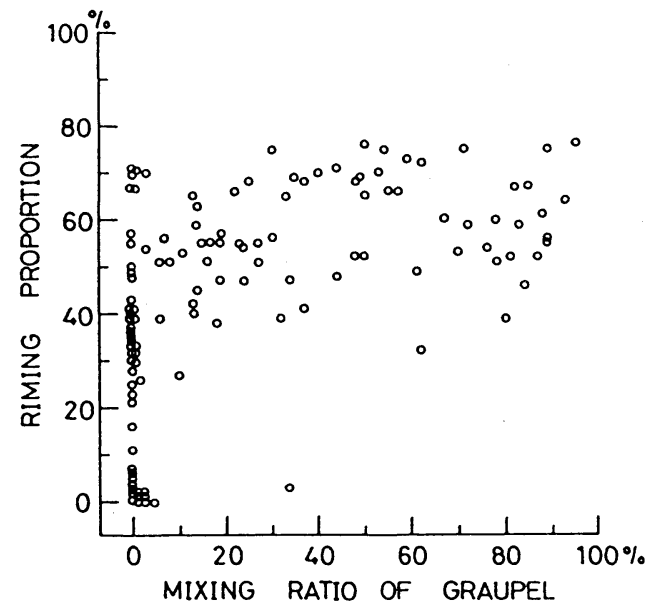

Fig. 7. The relationship between the mixing ratio of graupel and riming proportion in only snowflakes.

order to indicate the meteorological conditions during the snowfall, the radar echo patterns classified into the three types were used (diffused, convective, and band-shaped convective echoes). Overall, it is seen that the frequency of snowfall in which the riming process is predominant in snow particle growth (riming proportion $\geq 50 \%$ ) is about $70 \%$ of the total frequency of snowfall at the Shinoro site near the coast. Figure 8 also has a characteristic feature as follows. Although the riming proportion varies widely under weak snowfall intensity, only the snow particles with a large riming proportion fall under strong snowfall intensity. Namely, the lower limit of riming proportion tends to increase with the increase in snowfall intensity. The riming proportion is greater than $50 \%$ for cases of more than $2 \mathrm{~mm} / \mathrm{hr}$ in snowfall intensity. This means that in the coastal areas the riming process, not the deposition process, is responsible for strong snowfall intensity.
Even if the riming process is dominant, it happens naturally that the snowfall intensity is weak for cases of only small snow particles or a few number of snow particles per unit volume. In cases such as these, the riming proportion is large in spite of the weak snowfall intensity. These values are plotted in the upper left portion of Fig. 8 .

Although values of the riming proportion vary widely in the case of weak snowfall intensity, they can be clearly classified by the use of the radar echo patterns. Namely, even if the snowfall intensity has similar values, the riming proportion is less than abut $40 \%$ for diffused echoes and more than about $80 \%$ for band-shaped convective echoes. Those of convective echoes have intermediate values between the diffused and band-shaped convective echoes.

\subsection{The relationship between the growth stage of snow clouds and riming proportion}

It has been pointed out that graupel particles or densely rimed snow crystals fall along coastal areas while lightly rimed or non-rimed snow crystals fall on inland area (e.g. Magono et al., 1964, 1966). In order to clarify the reasons for this, the relationship between the riming proportion and the growth stage of snow clouds was examined.

The determination of the growth stage of snow clouds passing over the Shinoro site was accomplished with the use of radar analysis as follows. First, the echo cell passing over the Shinoro site was found in the Plan Position Indicator (PPI) and Constant Altitude Plan Position Indicator (CAPPI) radar data. Next, the echo cell was tracked. The upper portion of Fig. 9 shows the time change of the position of an echo cell on the PPI from 1940 JST to 2040 JST, 5 February, 1987 at an interval of ten minutes. It can be seen that the echo cell passed over the Shinoro site at 2020 JST. The outline of the echo cell for each time is represented by the contour of the strongest radar reflectivity factor with an interval of

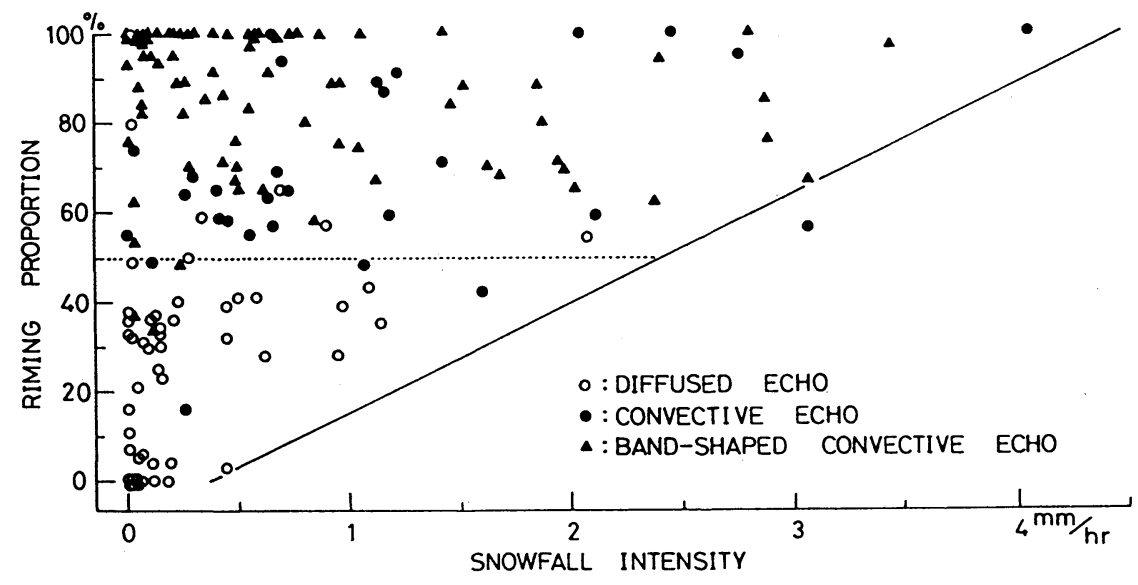

Fig. 8. The relationship between snowfall intensity and riming proportion. The classification of each radar echo pattern is indicated by the symbol given in the legend. 

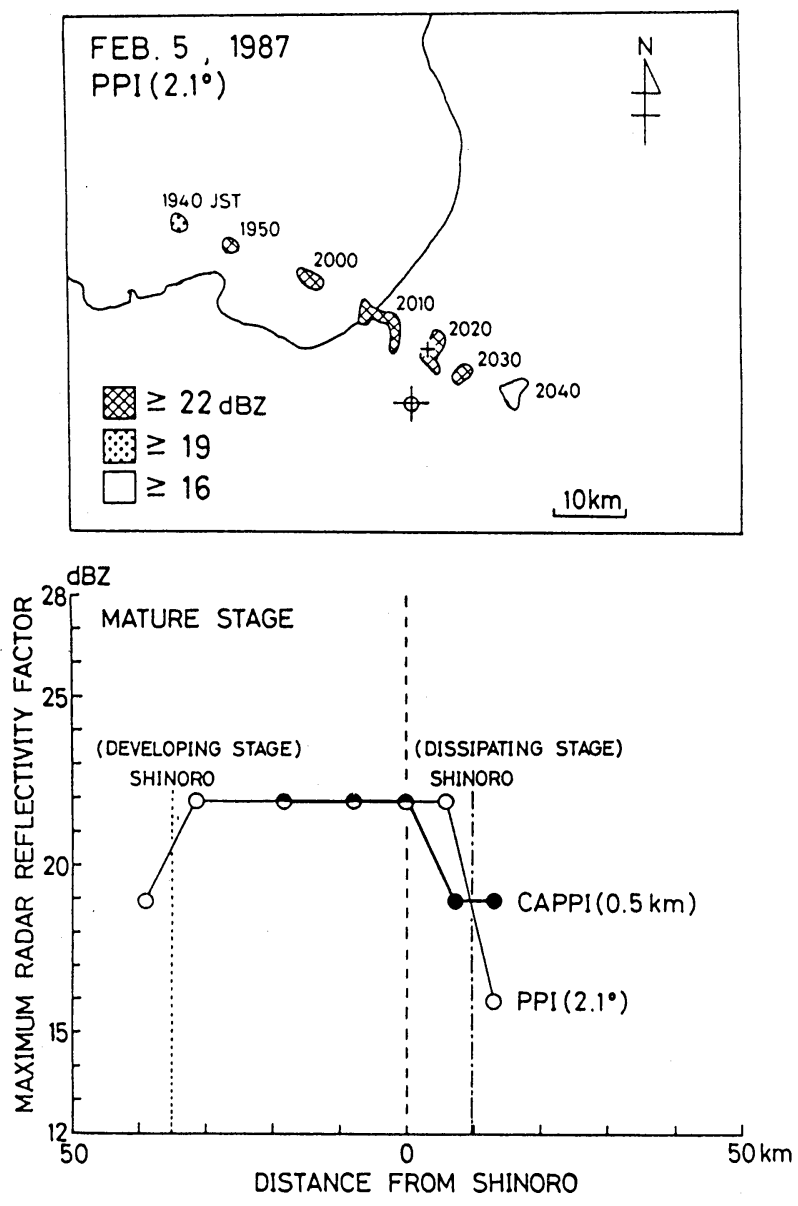

Fig. 9. Movement of the echo cell referred to as mature stage indicated by the maximum radar reflectivity factor in $3 \mathrm{dBZ}$ intervals (upper), and relationship between the distance from the Shinoro site and the maximum radar reflectivity factor of the echo cell (lower). The lower figure refers to the developing stages when the Shinoro site is located at the distance indicated by the dotted line and to dissipating stage when the Shinoro site is located at the distance indicated by the chain line.

$3 \mathrm{dBZ}$. It is seen that a weak echo cell developed prior to reaching the Shinoro site and decayed after passing the site. In order to clarify the development and decay features of the echo cell, its growth process is shown in the lower part of Fig. 9. Here, the distance from the Shinoro site is represented on the abscissa with the maximum radar reflectivity factor as the ordinate. The open circles with thin lines indicate values of the PPI radar data, while the solid circles with thick lines are values for the CAPPI radar data. If the peak of the maximum radar reflectivity factor is located over the Shinoro site as shown in this figure, it refers to the mature stage. If the peak is located to the rear of the Shinoro site,

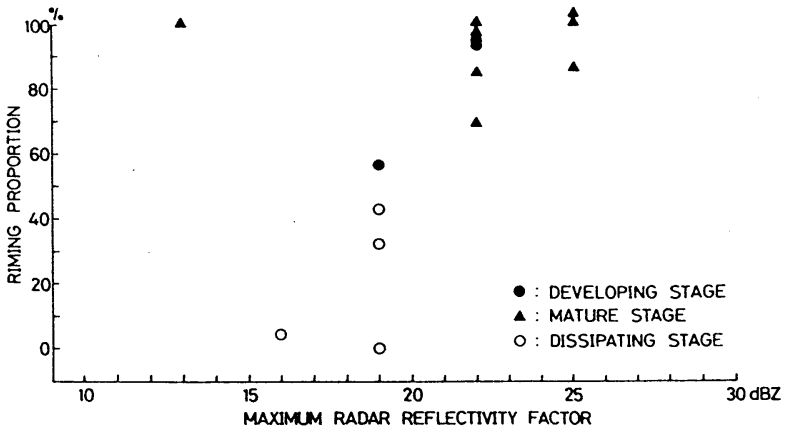

Fig. 10. The relationship between the growth stage of snow clouds and riming proportion. The growth stages are indicated by symbols given in the legend.

it refers to the developing stage. The other refers to the dissipating stage.

Snow clouds were classified into the three stages as described above, and the relationship between the growth stage and riming proportion was summarized, as shown in Fig. 10, for equal radar reflectivity factor. It is seen that the riming proportion is greater than $50 \%$ for the developing and mature stages, while less than $50 \%$ during the dissipating stage over a wide range of the radar reflectivity factor. This result shows that snow particles grow through the riming process in the developing and mature stages, whereas they grow through other processes in the dissipating stage.

\section{Discussion}

As it was shown above, the riming proportion during the developing and mature stages was greater than that in the dissipating stage. This result can be explained as follows. In the initial growth stage of snow clouds, a number of cloud droplets are first produced, with snow particles then gradually formed. As a result, the number of snow particles is much lower than the number of cloud droplets. Therefore, it follows that the riming process dominates the formation of snow particles falling in the developing and mature stages.

Generally speaking, as snow clouds move from the sea toward the land, clouds of the developing and mature stages pass over the coastal areas more frequently than over inland areas. Thus, based on the observational result that the riming proportion during the developing and mature stages was greater than that in the dissipating stage, it is concluded that snow particles falling over the coastal areas have greater amounts of rime than particles falling over inland areas. This hypothesis is supported by the present observational results. Namely, along coastal areas located within about $10 \mathrm{~km}$ of the coast such as the Shinoro site, snowfall in which the riming process dominates accounts for about $70 \%$ of total 
snowfall frequency. It is recognized that the riming process contributes greatly to the snowfall amount along coastal areas.

\section{Conclusions}

Measurements were carried out regarding the proportion of rime in snow particles. The results can be summarized as follows. Snowfall, in which the riming process was predominant in the growth of snow particles, accounted for about $70 \%$ of total snowfall frequency along the coastal areas toward the Japan Sea. The lower limit of riming proportion tended to increase with the increase in snowfall intensity. Also, in the case where the snowfall intensity was greater than $2 \mathrm{~mm} / \mathrm{hr}$, the riming proportion was greater than $50 \%$. This means that over the coastal areas the strong snowfall intensity, does not result from the deposition process, but from the riming process instead. This marks the first time that quantitative results were obtained of the characteristic time changes of snowfall intensity and riming proportion during the passage of snow clouds.

Typical values of riming proportion changed with the meteorological conditions described by radar echo patterns. Namely, the riming proportion was below $40 \%$ for the diffused echoes, about $60 \%$ for convective echoes, and about $80 \%$ with bandshaped convective echoes.

The riming proportion changed according to the growth stages of the snow. clouds. Namely, the riming proportion was greater than $50 \%$ during the developing and mature stages and less than $50 \%$ during the dissipating stage. Since the snow clouds of developing and mature stages pass over coastal areas more frequently than over inland areas, it can be understood why the riming process is predominant in the snowfall over coastal areas. Future studies should be conducted to determine if the riming process does or does not contribute to a great extent to the growth of snow particles over inland areas.

\section{Acknowledgments}

The authors would like to express their thanks to Mr. S. Kato and Mr. F. Ishioka of Hokkaido University for their support during the field work. The authors are also grateful to reviewers for their valuable and detailed comments. Funds for this research were supported by a Grant-in-Aid for Scientific Research from the Ministry of Education, Science and Culture of Japan.

\section{References}

Fujiyoshi, Y. and G. Wakahama, 1985: On snow particles comprising an aggregate. J. Atmos. Sci., 42, 1667-1674.

Harimaya, T., 1975: The riming properties of snow crystals. J. Meteor. Soc. Japan, 53, 384-392.
Harimaya, T. and M. Sato, 1989: Measurement of the riming amount on snowflakes. J. Fac. Sci., Hokkaido Univ., Ser. VII, 8, 355-366.

Higuchi, K., 1963: The band structure of snowfalls. J. Meteor. Soc. Japan, 41, 53-70.

Hobbs, P.V. and Collaborators, 1971: Studies of winter cyclonic storms over the Cascade Mountains (19701971). Res. Rept. 6, Dept. Atmos. Sci., University of Washington, 360 pp.

Konishi, H., T. Endoh and G. Wakahama, 1988: A new snow gauge using an electric balance. (in Japanese with English abstract), Seppyo, 50, 3-7.

Magono, C., K. Kikuchi, T. Kimura, S. Tazawa and T. Kasai, 1966: A study on the snowfall in the winter monsoon season in Hokkaido with special reference to low land snowfall (Investigation of natural snow crystal VI). J. Fac. Sci., Hokkaido Univ., Ser. VII, 2, 287-308.

Magono, C., K. Kikuchi, S. Lee, T. Endo and T. Kasai, 1964: An observation of snow crystals and their mother cloud (Investigation of natural snow crystals V). J. Fac. Sci., Hokkaido Univ., Ser. VII, 2, 123148.

Mitchell, D.L., R. Zhang and R.L. Pitter, 1990: Massdimensional relationships for ice particles and the in; fluence of riming on snowfall rates. J. Appl. Meteor., 29, 153-163.

Reinking, R.F., 1975: Formation of graupel. J. Appl. Meteor., 14, 745-754.

Reinking, R.F., 1979: The onset and early growth of snow crystal by accretion of droplets. J. Atmos. Sci., 36, $870-881$. 


\section{海岸部に降る降雪粒子における雲粒捕捉成長寄与率 \\ 播磨屋敏生・佐藤 節 ${ }^{1}$ \\ (北海道大学理学部地球物理学教室)}

1 個の降雪粒子の成長における昇華、雲粒捕捉、雪片形成成長過程の各々の貢献度を調べることは降雪 粒子の形成と降雪機構の研究において重要である。季節風吹き出し時に、降雪粒子の成長に占める雲粒捕 捉成長過程の割合を Harimaya and Sato (1989) の方法で測定した。日本海側の海岸部における降雪回数 のうちで雲粒捕捉成長過程が卓越している降雪（全質量に対して付着雲粒量が $50 \%$ 以上を占めるような降 雪）は約 $70 \%$ あった。海岸部での降雪粒子の成長において昇華成長過程は強い降雪強度をもたらさない が、雲粒捕捉成長過程は強い降雪強度をもたらすことが観測された。

一般的に言えば、降雪雲は海上からやってきて内陸で消滅するので、内陸部より海岸部を発達期と最盛 期の降雪雲が通過することが多い。観測結果によると降雪雲の発達期と最盛期では、雲粒捕捉成長過程が 卓越していた。それでそのような降雪雲がよく通る海岸部では、雲粒捕捉過程による降雪粒子の成長が卓 越することになる。 